\title{
Picturing the Boundary Between Good and Bad: The Lighting, Framing, and Camera Movement of "Kidnap"
}

\author{
Tedjorahardjo, C.A. \\ English for Creative Industry, Faculty of Letters, Petra Christian University, Siwalankerto 121-131, Surabaya \\ 60236, East Java, INDONESIA \\ Email: m11413028@john.petra.ac.id
}

\begin{abstract}
This creative work is a cinematography report from the screenplay "Kidnap" by Indah Sari Y. The story tells about a criminal who is given a mission to kidnap the daughter of a deceased wealthy CEO, however the Man realized that he mistakenly kidnapped the wrong person. He is caught in the dilemma whether or not to let her go, yet his situation only gets worse when he is given the order to kill her. The cinematography of this film aims to convey the story and message that the director envisioned. Moreover, it aims to portray characterization through various elements of cinematography such as framing, lighting, and camera movement. It also intents to manipulate tone and mood through those cinematographic elements. To further understand the cinematography of this film, three main theories are used: low-key lighting, head-room and lead-room, and handheld camera movement. These theories are to help the cinematographer to convey the genre of psychological suspense, with the subgenre of crime drama. An in-depth analysis in this report will talk in details about how cinematography achieved the desired effects towards characterization, mood, and tone.
\end{abstract}

Key words: Cinematography, Textual analysis, Low-key lighting, Handheld camera movement, Lead-room and head-room

\section{INTRODUCTION}

Film is a medium which relies heavily on visual story telling because instead of telling a story, it actually shows a story. This way cinematography plays a very crucial role in a film and it becomes one of the most important one. With films created for widescreen viewing, the visuals are what captures the audience attention the most and it absorbs the audience to enter the world they are looking at. A cinematographer's role is to combine together miss-en-scene, camerawork, and framing all together to create the tone and mood that can supports the storytelling.

As my final project, I created the cinematography of the short film "Kidnap", a screenplay which tells the story of a man who abducts a woman as a task from his boss and he struggles to get a code to her family's company vault. The Man then has to make a fatal decision as he found out that he kidnapped the wrong person. The director of this short film has some directorial vision upon the making of this film. First, the director wanted the film to implicitly tell the kidnapper's background that is not entirely explained through the dialogues and story line. Through the Man's background, the director wants to make him the protagonist of the story. Also, the director's other vision is to blur out the boundary of good and bad so that the audience will not expect a plot twist in the end, which tells that the kidnapped Woman is actually the antagonist. These points, were not included in the story line. Considering these directorial visions, the best way to convey those elements through a visual storytelling is through the lighting, framing, and camera movement because "The camera is your audience's eyes into the world you capture." (Lindblom, 2015) Therefore when the camera moves, it is like making the audience to move with the cinematographer's eyes. Any specific camera movement or a perspective can give the people who sees it a certain feeling. 
The purpose of this film is to convey the story and message that the director wants to tell to the audience. Moreover, I wish that the audience may perceive that the tone and mood can be manipulated through the use of framing, lighting, and camera movement. I also want that the characterization is to be demonstrated through the various elements of cinematography such as framing, lighting, and camera movement.

Through the cinematography of this film, I hope that the audience will able to see the inner conflicts of the male kidnapper as a protagonist through the visual elements of framing, lighting, and camera movement. In the story, the Man was introduced as a bad person with him verbally abusing the lady he kidnaps. His acts are emphasized especially through a very chaotic and shaky camera movement because it makes his actions look more violent. On the second act, however, I hoped that the audience can feel his isolation and his confusion through the still camera movement and hazy lighting. Until the end of the film, I keep on adding more elements such as a still shot with a shaky camera movement and tighter framing on the Man in order for the audience to sympathize with the Man more than the Woman. By doing so, I want the audience to feel how the character is revealed from the surface and then deeper into his feelings. This evolution will tell the audience that a person who at first seemed bad, might have a story behind them and therefore the audience would be able to sympathize to his story.

Also, through the evolving shots of the Woman, I hope that the audience would be able to see the two side of the weak or those who looked like the good people. I tried to create a dynamic picture throughout the entire length to show the true image of the Woman, in a way that the audience might not realize it. In contrast of the Man, I am trying to make audience unable to guest the true colors of the Woman. If made clear, the plot twist of this story will not be as effective. The dynamic shots is there only for audience to recall back that the Woman has been the one who is suspicious from the beginning. At the end, through sudden movement of the Woman's static shots in the beginning, the Woman's change must then be clear. These cinematography elements of framing, lighting, and camera movement are very important in this film because these elements portray the underlying message about the characters that are not verbally stated through the script.

In making this film, I applied three theories of lighting, framing, and camera movement. Regarding film lighting, I used the Low Key Lighting Theory. Low Key lighting boomed from the darker days of Italian Neorealism, French New Wave, and German Expressionism, with the characteristic of their high contrast, dark shadows, and half lit sets and faces. Unlike High Key lighting which leaves a sense of safety and positivity Low Key lighting are interpreted in relation to the feelings of danger, suspense, depression, mystery, and evil (Poland, 2002). Therefore, it is proved that lighting condition has the power to accentuate suspense in a narrative and it is able to provide a baseline for the audience emotional response (Alton, 1995). Therefore, Low Key lighting, along with the contrast and dark shadow, will best suit this film with the genre of psychological suspense because it is able to evoke the audience with the feeling of danger, suspense, and mystery.

The second theory that I applied is the Handheld Shot camera movement theory. Camera movement is one of the cinematographer's tool to give the audience more understanding of a character's behavior. It assists in surfacing the action and behavior while being true to the character's innermost psychological state (Nielsen, 2007). Handheld camera movement has been extremely popular through documentary films, which are shot under an abrupt, rather unplanned, and unexpected conditions. French filmmaker Jean Rouch coined the term Cinema Verite or "Truthful Cinema" during the heap of the French New Wave. In the French New Wave, films like Godard's Breathless (1960) is known with the use of handheld camerawork to heighten tension. Many films today, however, starts to embody this handheld method both partially and entirely. Nowadays in commercials, TV, and especially Hollywood films, this handheld method is widely practiced and is now very common (Alrbight, 2011). Intense action movies like Hurt Locker (2008) or Bourne Ultimatum (2007) uses this freeform method to give a sense of disturbance and violence. This way, it seems like the action and movement of the actors does not seemed to be preplanned or rehearsed (Brown, 2012). It comes with the sense that the audience are there to directly witness the scene and it gives the feeling as if the scene is really happening. Therefore, 
it shall give the element of surprise and intensity to the audience, since the camera is able to move anywhere, anytime, with any trigger.

Finally, I used the framing theory of Head-room and Lead-room. Headroom and lead-room are two of the basic composition rules in photography and cinematography. Both rules were established to give a balance and positive space in a picture. In photographing or cinematographing people, especially in medium and close up shots, the headroom is given above the head to make sure that there is a balance in the composition of the frame. Lead room is also given in the frame as a space where the dramatic energy is driven into (lightsfilmschool,n/d). Lead room can also mean the nose-room or looking-room, a direction towards which the actor is facing. It gives the sense of action of movement, as if the frame has its own direction. However, to achieve the contrary effects means to break these standards. Giving less head-room and lead-room, for some filmmakers, are intended to give the shot a strange sense of balance and a feeling of discomfort. Less head-room mostly applies in close-up shots, also called as chokers. As its name describes itself, it "chokes" the character to give it less place to breathe. Therefore, it gives the character a choke, putting him in a disturbing situation.

With these three theories I am going to use to demonstrate the techniques that I used in shooting this film to create the achieved tone and mood of this film.

\section{CONCEPT AND ANALYSIS OF THE CREATIVE WORK}

\subsection{Modes of Expression}

The genre used in this film is psychological suspense together with the subgenre of crime drama. The act of kidnapping, which become the main issue of this film, belongs to the subgenre of crime drama. However, unlike any crime drama which follows on the themes of the crime itself, this film wants to talk more about the psychological issue happening between the Man and the Woman, also the conflict between the Man's conscious and mind. The genre psychological suspense would fit perfectly, because a psychological suspense explores the process of the mind, creating suspense from the mind instead of mere physical feeling of suspense.

With this concept and with an in-depth discussion with the director of this film, I planned each frame and put them into the form of a storyboard. Planning the storyboard became one of the most challenging part of the production, because it is where all the crucial decisions of effective story telling are made. Since the film is made to mislead the audience by blurring out any clue about the roles of the characters (whether they are good or bad). Furthermore, since it will end in a plot twist, I decided to twist all the intentions of the shots and camerawork. Gradually as the story goes on, the camerawork will also change to suit the mood and to suit the psychological condition of each character. The Woman, in the first act, must look helpless before the Man and in the other hand, the Man looks much stronger. As the film goes on to the second scene, with a slower pace and cuts, the focus starts to shift to the Man with his dilemma. There are more shots that is made to focus on the Man. Yet, it is not yet clear that the Man actually has a deeper problem than the Woman. And finally on the last scene where the boss appears, we finally discover the Man's confusions and his position - that he is not the villain but also a victim.

\subsection{Genre Codes and Conventions}

In this section, I would like to dig more about genre codes and conventions that a psychological suspense film, such as Kidnap, uses. I am going to list the characteristics of the cinematography of a psychological thriller film, and compare it to what I have used in shooting my film. I retrieved these codes from Joyce G. Saricks's The Readers'Advisory Guide to Genre Fiction.

\begin{tabular}{|c|c|c|}
\hline Cinematography & $\begin{array}{c}\text { Genre } \\
\text { Elements } \\
\text { Psychontion of } \\
\text { Suspense }\end{array}$ & Genre Convention of My Creative Work \\
\hline
\end{tabular}




\begin{tabular}{|c|c|c|}
\hline Lighting & $\begin{array}{l}\text {-Low Key } \\
\text { Lighting } \\
\text {-Less highlights, } \\
\text { more shadow }\end{array}$ & $\begin{array}{l}\text { The lighting set up that I made was a low key light. } \\
\text { The general tone of the film is dark, having a lot of } \\
\text { shadows and very less highlights. The lighting tools } \\
\text { that I used were only tungsten lightbulbs for the } \\
\text { room light, small } 150 \mathrm{~W} \text { Dedo lights for rim light and } \\
\text { ambient light, and Lumos Light for fill lights (see } \\
\text { Appendix C). With that setup, I used } 500 \text { ISO for the } \\
\text { camera, using a low sensitivity light sensor. }\end{array}$ \\
\hline Framing & $\begin{array}{l}\text {-The framing is } \\
\text { tight, having a } \\
\text { claustrophobic } \\
\text { feel to it. } \\
\text {-Entrapment of } \\
\text { the mind, planes, } \\
\text { or house. }\end{array}$ & $\begin{array}{l}\text { I made the Woman seemed intimidated and } \\
\text { threatened by the Man's behavior. First, I made her } \\
\text { frames tighter than the Man's frame by adding more } \\
\text { portion of the Man's back over his shoulder. This } \\
\text { will make her seemed cornered inside the frame. } \\
\text { There was also only one main location with two } \\
\text { different room. As a miss-en-scene, the location } \\
\text { reflects how the Man is entrapped inside his } \\
\text { problems. I made the hanging lamps dangle low so } \\
\text { that the ceiling will look lower, and therefore } \\
\text { looking more entrapping. }\end{array}$ \\
\hline Camera Movement & $\begin{array}{l}\text {-Handheld shot, } \\
\text { used to heighten } \\
\text { tension and give } \\
\text { realism. } \\
\text {-Gives elements } \\
\text { of surprise to the } \\
\text { story }\end{array}$ & $\begin{array}{l}\text {, I made the camera movements handheld and } \\
\text { following the actors' movement naturally - both the } \\
\text { Woman and the Man. It will lead the audience to feel } \\
\text { as if they are looking at the scene for real like a } \\
\text { documentary. } \\
\text { Also, the shaky feel that a handheld camera } \\
\text { movements possess gives an uncertain feeling of } \\
\text { what will happen next. It feels like the camera can } \\
\text { go anywhere. This gives the audience an effect of } \\
\text { anxiety. }\end{array}$ \\
\hline
\end{tabular}

\subsection{Frame-by-frame Cinematography Analysis}

To show my creative work and how I achieved the desired impacts of this film, I am going to prove how I applied the director's vision into the cinematography of this screenplay, especially its framing, camera movement, and lighting. The goal that I would like to achieve through my cinematography is first, to achieve a certain mood and tone that will be carried out throughout the entire film. Second, I would like to portray the characterization of the characters.

\subsubsection{Mood and Tone}

The first goal of my cinematography is to achieve a certain mood and tone that will be carried out throughout the entire film. The mood and tone will create a certain atmosphere that the audience will feel and grasp while they are watching the film.

\subsubsection{Contrasting panic and serene mood.}

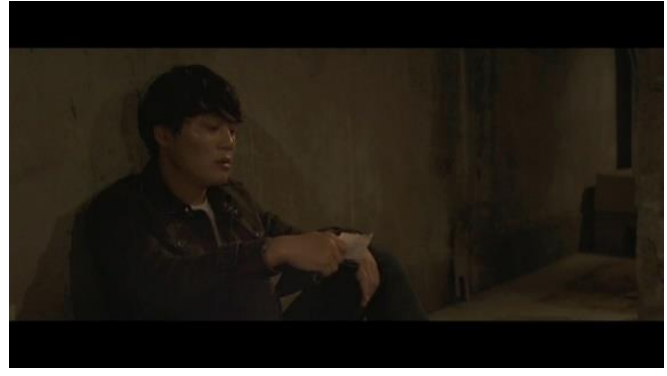

Picture 1a

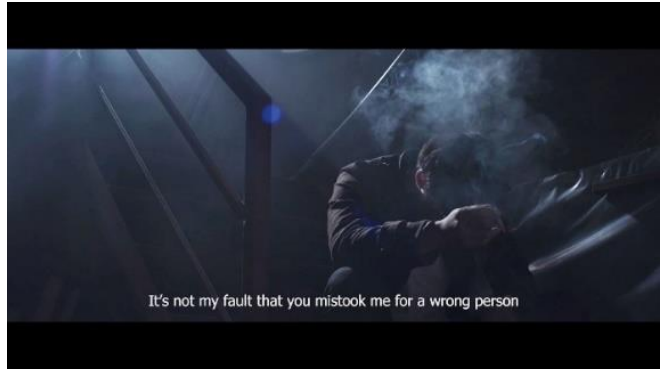

Picture $1 b$ 
Throughout the film, the kidnapper reacts with different actions, each surrounded by different mood. These moods can be classified into two major moods: panic and serene. Both of them are mostly shown through the camera movement, because camera movement has the strongest impact on the audience.

To display an isolation towards the Man in his serene moments, I used a still shot which can feel more meditative with its slower pace. When compared to the other moving handheld shot, the contrast should be felt by the audience. Additionally, as seen in picture $1 \mathrm{a}$ and $1 \mathrm{~b}$, the framing that I used has a lot of breathing room and headroom, making the character to look as if he is lost in the frame (Brown, 2012). In picture $1 \mathrm{~b}$, however, there is less nose room in front of the character than picture 1a. This was done to make the Man look more suffocated and stuffed after the incident where the Woman got a panic attack.

The lighting in picture 1a was also done to create the atmosphere of haziness and confusion in the Man's moment of contemplation. To create this scene, a cloud of fog was sprayed into the entire room. The light source was a $1 \mathrm{k}$ tungsten light with a blue filter placed at the top of the stair. With the presence of the fog, the light will have a streaming texture pushing down towards the Man. Also, the fog will enable the smoke from the cigarette to be more visible, enhancing the haze in the frame.

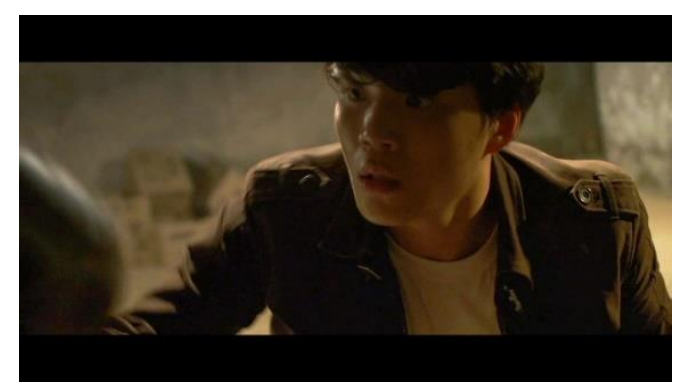

Picture 2a

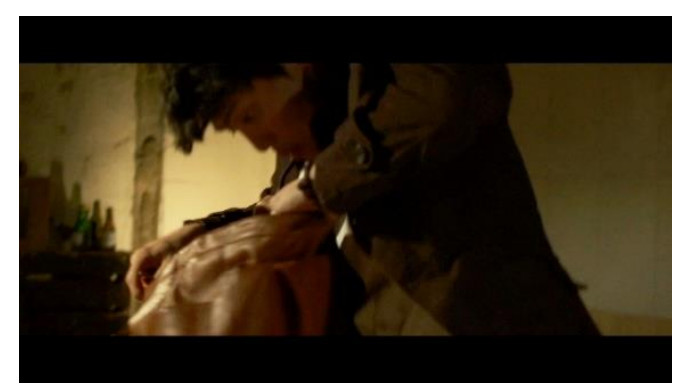

Picture $2 b$

On the contrary, when the Man is in a moment of panic, I used a different techniques to convey the mood. First, the framing on the Man is much tighter, giving him a sense of confinement and suffocation. The headroom was cut down, resulting in a cut-down of the actor's breathing room. (lightsfilmschool,n/d)

Secondly, the camera movement that I used is a very shaky camera movement. I tried to create the feeling achieved by action or suspense movie by using a handheld camera technique. With a lot of movement of the camera, there is less certainty of where the camera is going next - as if there is no certainty of what is going to happen next. A handheld technique also has the documentary film feel into it, making the audience feel like they were there to witness the scene. This will give more tension to the audience

\subsubsection{Characterization}

Next, I would like to talk about how I practiced the cinematography of this film to portray the traits of the characters. The main two characters - the Man and the Woman - in this film each has their own unique feelings and emotions that has to be portrayed. 


\subsubsection{The Decoy of the Woman's Innocence}

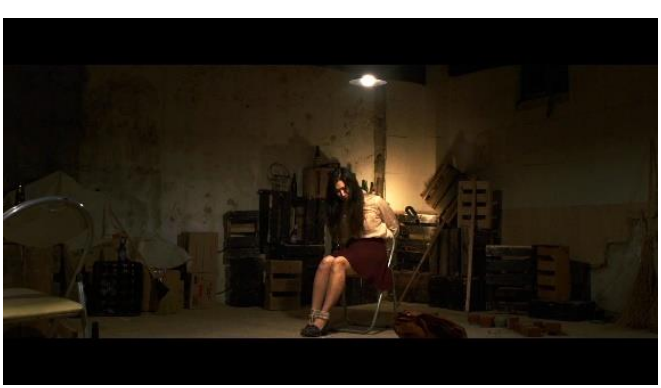

Picture $3 \mathrm{a}$

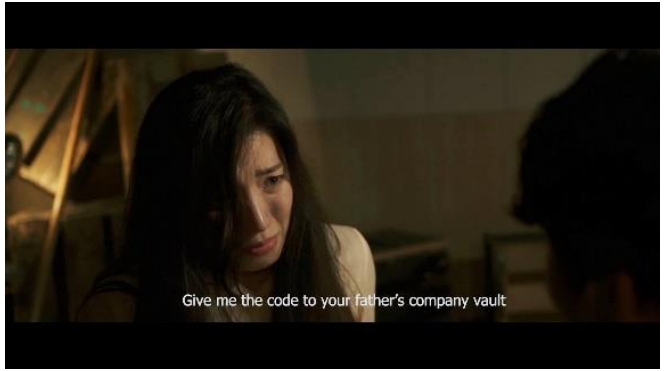

Picture $3 b$

First, I would like to talk about the character of the Woman. The Woman is a character which changes throughout the entire film. She evolves from being innocent into revealing that she is the boss of the organization which the Man is going to enter.

In picture 3a, the audience can see that the Woman is placed in the center of the frame. With this position, it makes the Woman the center of the attention. This is also supported by the placement of the light that acts like a spotlight in that frame. The lighting streams down on the Woman, contrasting with her dark surrounding. It is as if the entire film is going to tell her story - as if the weight of the world is on him at this instant. (Brown, 2012) With the Woman being placed in such a way, the audience would think that she is the innocent one in the film.

The scene shown in picture $3 \mathrm{~b}$ wants to focus on what is happening between the Man and the Woman as they talk, the camera movement is a handheld and fluid camera work which follows according on how the actors move. Also, this kind of movement gives the sense that the actor's action are not preplanned (Brown, 2012), giving the audience a feeling of uncertainty and surprise as the Man becomes more tormenting towards the Woman. Through all these elements, the audience will sympathize towards the Woman as if she is the innocent one in the film.

\subsubsection{The Woman as She Reveals Her True Self}
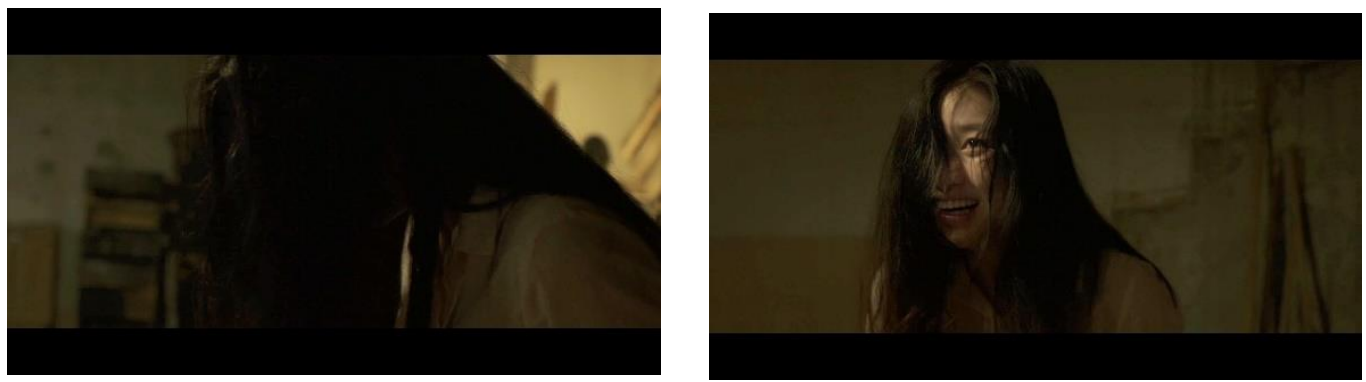

Picture $4 \mathrm{a}$

Picture $4 b$

In this part, the Woman who seemed to be the victim now reveals herself. Picture $4 \mathrm{a}$ and $4 \mathrm{~b}$ are in one same cut and are both done in one movement. The framing that I used in Picture $4 \mathrm{a}$ and $4 \mathrm{~b}$ was a close up shot, because I want the audience to focus entirely on her expression as she laughs off the kidnapper. The camera movement was a round dolly that starts on her side (picture 4a), goes around for ninety degrees (picture $4 \mathrm{~b}$ ), and stops in front of her. This movement is done to as if to show her transformation and revelation, moving from a picture with less information into another with more. I 
started on the shoulder because at first she was crying and her shoulder shakes, and when she laughs her shoulder is also shaking. Then, I focus on her face to reveal that she is actually laughing. A round dolly is one effective way to slowly uncover more and more details as the shot moves around the character.

To create the effect of mystery, I used the same lighting method that I used previously: I used only the key light to give a certain highlight and to create a contrast on the other side of the face. In a way, the Woman is put in a position between good and bad - as she leaves her good side and embrace the dark side. This method is inspired by the lighting used in film noir, in which side-lit close-up is frequently used. According to Blain Brown in his book Cinematography: Theory and Practice (2012) p.69, he mentioned that "Beyond narrative, it becomes part of character as well - noir was the birth of the protagonist who is not so clearly defined as purely good or evil. ... In their very being, they may be pulled between good and evil, light and dark, illumination and shadow."

\subsubsection{The Man's Guilt}

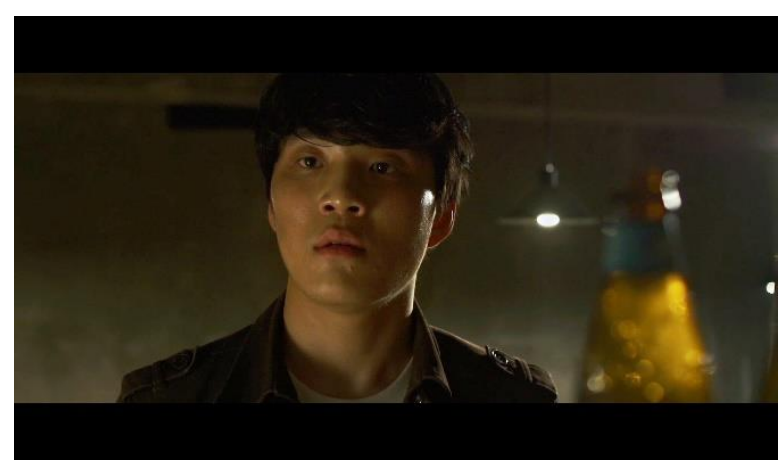

Picture 5

Next, I will talk about the characterization of the Man through the cinematography. This time the Woman suddenly talks about the Man's family and he was struck by that statement. He felt guilty about his deeds.

As shown in picture 5, the framing to show guilt is a close up so that audience can focus on the kidnapper's face while he listens to the now mysterious victim's voice on the back. A bottle is included inside the frame as a foreground to make the frame look more stuffy and full. In a way, there are not many space in the frame for the actor to "breathe", and that serves the purpose of making the frame less comfortable for the character. There is also an awkward amount of lead room, which adds the discomfort of this framing.

The lighting that I used was a rather normal lighting with a key light and a very soft fill light to show the details of his expression. Since the shot lingers long on the face, I want the audience to be able to see the Man's face clearly. However I still give a little contrast of the two side of the face to show that he is in between the good and the bad side of himself. 


\subsubsection{The Man's Confusion}

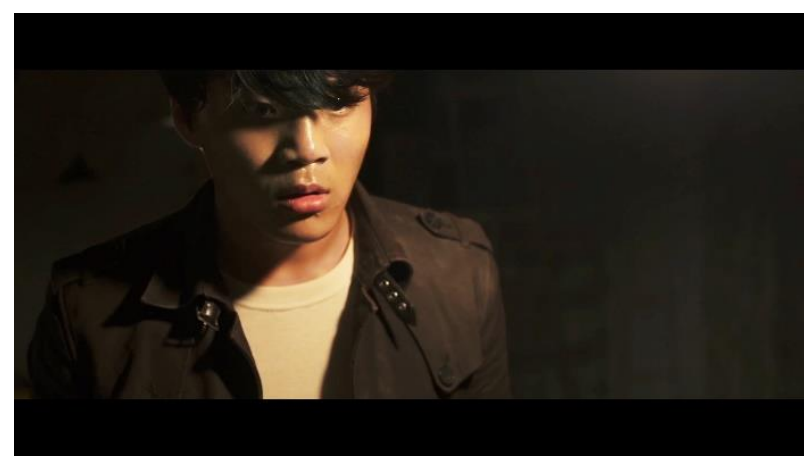

Picture 6

In this scene, the Man is shocked that the Woman does not die after he shot her three times. I would like portray his inner feelings about this situation. As shown is picture 6 , the Man is framed in a very tight and uncomfortable close up. Intentionally, the headroom of the man is eliminated until below his head. "A tighter headroom can make a character look constrained, as if in a room with low ceiling." (Mamer, 2009, p.150) This is to show that he is uncomfortable about the situation, because the Woman is still alive even after he shot her.

Though this frame is a fixed shot that does not have any big camera movement, I used a handheld grip to give a small movement to show his confusion and his mixed feelings inside him. This was done because a camera movement can also evoke psychological and emotion activity (Nielsen, 2007). I used the small camera movement to show that he is confused and very much uncomfortable inside about the situation - how the Woman is not dead after he already shot her three times.

In picture 6 the audience can see how the sharp lighting gives a contrast in his face. The direct light source from the ceiling lamp as a key light hits the kidnapper's hair directly. Therefore that leaves the face with an uneven shadow from the hair. The result is that it gives the kidnapper a more confused look and a messier situation inside his face.

\section{CONCLUSION}

The process I went through in preparing this project from script into a picture was not easy. Starting from the script, I discussed with the director about her vision of the movie. From her vision I gathered references from other movies regarding how they deliver the feeling of the characters through the camerawork. Then, I started to make the storyboard to integrate every single part of the story. I went back and forth from testing the shot with a real camera and revising the storyboard several times, before I finally come up with the finalized shot done in the shooting. All these process, however, was not as easy as it seemed to be.

Going back and forth from storyboard to a footage is one of the process I will now always keep in mind. What was composed on a paper and composing it in front of camera could be totally different. What was preplanned sometimes turns out to be impossible to do - because when composing an image on the story board, I simply put objects wherever I like without imagining how to put it on a real space. Other times, the angle I imagined cannot really be done when it comes with the real person acting in front of the camera. This is what makes the preparation of making even a really short film very long because there needs to be a repeated process of drawing figures and shooting real people. This process, however, I believe is a part of the practice required to create better pictures.

Working on a short psychological suspense with a subgenre of a crime drama is a good experience for me to explore a deeper side of cinematography. When watching low budget short films, I sometimes find how the cinematographer does not really bother to design each shots with a purpose. 
Most of them only cares for the looks, whether the frame is pretty or not. However, this psychological genre has allowed me to dig deeper and design deeper into the frames I created. With psychological genre, I had to think how to make every second counts in delivering the story and the characters. It is most important for me that my frames tells its own story along with the story of the film. Finally, I think the experience of making a film is a challenging task, yet it stimulated me to grow more in the understanding of a deeper knowledge in film itself. To be able to create a good film is not an instant task - it takes time and a long process in order to be able to create good pictures and inspiring stories. I hope that more cinematographers will realize this fact and will create pictures that tells stories.

In a bigger picture, I would want to contribute to Indonesia's blooming film industry. For years, people in Indonesia has appreciated western and foreign movies more than its domestic artworks. These days, however, we started to appreciate our own films, as we are starting to make better movies then before. Indonesia's film is now able to compete in the international festivals, though in my opinion, it has not really stood up among them. As someone who studies abroad, I am able to stand in the middle of both the international viewers and a domestic filmmaker. Thus it will enable me to have better visions as a cinematographer, knowing what makes a film well accepted in the international audience while lifting up local issues and stories.

\section{REFERENCES}

Albright, M. (2011) The Visible Camera: Hand-Held Camera Movement and Cinematographic Embodiment in Autobiographical Documentary

Alton, J. (1995). Painting with light. Berkeley: University of California Press.

Bordwell, D., \& Thompson, K. (2010). Film art: an introduction. New York: McGraw-Hill.

Brown, B. (2012). Cinematography: theory and practice: imagemaking for cinematographers and directors. Amsterdam: Elsevier.

Filmmaking: Lead Room, Head Room \& Anticipatory Framing. (n.d.). Retrieved May 26, 2017, from https://www.lightsfilmschool.com/blog/lead-room-head-room-framing/1669

Filmmaking Tutorial: Framing Heights \& Composition Tips. (n.d.). Retrieved May 28, 2017, from https://www.lightsfilmschool.com/blog/framing-heights-composition/1675

Hayward, S., (2013). Cinema studies. The key concepts. 4th, rev. ed. Andover: Routledge Ltd.

Joyce G. Saricks. (2009) The Readers' Advisory Guide to Genre Fiction (2 ${ }^{\text {nd }}$ ed.) American Library Association: Chicago.

Lindblom, O. (2015, September 2). Use Your Camera to Control Audience Perspective. Retrieved February 6, 2017, from https://www.videomaker.com/article/c18/17682-use-your-camera-tocontrol-audience-perspective

Lombard \& Ditton. (September 1997). "At the Heart of It All: The Concept of Presence" Journal of Computer Mediated Communication.

Mamer, B. (1996). Film production technique: creating the accomplished image. Belmont: Wadsworth Pub.

Nielsen, J. I. (2007). Camera movement in narrative cinema: towards a taxonomy of functions (Unpublished doctoral dissertation). Ph.d.-afhandling.

Poland, J. L. (2002). LIGHTS, CAMERA, EMOTION! AN EXAMINATION ON FILM LIGHTING AND ITS IMPACT ON AUDIENCES' EMOTIONAL RESPONSE (Unpublished master's thesis). Cleveland State University.

Stoller, B. M. (2009). Filmmaking for dummies. Indianapolis, IN: Wiley Pub., Inc. 